\title{
Design for the Transition Movement: Designing a Post-Consumer Society
}

\author{
Livia Santana Fauaze $^{1 a}$, Ana Beatriz Simon Factum ${ }^{1}$ and Paulo Fernando de Almeida Souza ${ }^{1}$ \\ ${ }^{1}$ Federal University of Bahia, Graduate Program in Visual Arts, Salvador (BA)
}

\begin{abstract}
Capitalism and consumerism have brought drastic outcomes to society so that, in contrast, an increasing number of initiatives have also come up with the purpose of thinking about new models and new referentials of success and socio-environmental development. In this context, this article proposes to investigate the design contributions to this transition movement, which aims to build a more just, responsible and sustainable society. By means of a literature review, this study characterizes the current society, presents the transition movement concepts and approaches design for complexity. Finally, the role of creative leadership and the design contributions in this process are discussed considering examples.
\end{abstract}

Keywords. Design, Contemporary challenges, Creative Leadership, Transition Movement

\section{Introduction}

The paradigm shift is inevitable and urgent for life maintenance on the planet. This transition that is observed in the contemporary world is characterized by questioning the outcomes of capitalism, frenetic consumerism and the adopted socio-economic development frameworks. Thus, in order to deal with the contemporaneity challenges and bearing the desire to project another society in mind, initiatives of different natures come up, experimenting with new economic models, stimulating the adoption of environmentally responsible attitudes and establishing new social development premises.

This article was motivated by the chance of studying the possibility of design as a catalyst, aiming to study the design collaborations in this transition movement. It is justifiable to see efforts being made to broaden the discussion of current problems and possible solutions, and this way there is hope to inspire and encourage other professionals to work on building a new model of society.

A literature review was conducted based on a theoretical-exploratory methodology, and using the deskresearch procedure. The collection of digital and printed books, scientific articles and dissertations was elaborated considering the following key words: Design, transition movement, social and environmental impact, and the texts that had greater affinity and relevance for the theme were recorded.

The starting point is the contextualization of the present atmosphere that we live in, followed by the Transition Movement concepts, then, considerations about the Design for Complexity and finally, a reflection on Creative Leadership, by means of initiatives that aim for an engaged protagonism.

It is worth mentioning that this is a master's degree research in progress, associated with the 'Art and Design: processes, theory and history' research line from the Visual Arts Graduate Program at the Federal University of Bahia - UFBA.

\section{Zeitgeist: the atmosphere of the 21st century}

As a consequence of the mercantilism expansion, the industrial revolutions, and with the advent of capitalism and the world wars, theories and movements that oppose the socioeconomic development model characterized by consumerism and income concentration have emerged, proposing a more responsible attitude towards socioenvironmental issues as authors Schumacher (1983) and Manzini (2008) defend.

There is no denying that the Industrial Revolutions promoted improvements in society, health and education, and they increased life expectation and the living standards as well. The technological advances brought more comfort, daily facilities and greater food production. But on the other hand, they had profound implications for the reason that they were oblivious to the premises that were established as development, as argued by Braungart and McBonough (2013).

The purposes established until the 1960s changed together with the world, and, at the time, the priority was mass production and in large quantities. According to Cardoso (2012), the contemporary industry is conducted

a Corresponding author: livia.fauaze@gmail.com 
in a more flexible and fragmented way, aimed at creating differentiated products. According to the author, the world divided between right and left was replaced by economic liberalism in the globalization context. Unlike nowadays, in this past, when there were no computers, internet or digital culture, little thought was given to environmental responsibility.

A consumer culture was established and it shaped postmodern man, who adopted the concept of social status through products of a fashion that has been intentionally changed all the time, completely ignoring the planet capacity and limits. "Within the last 50 years, we have consumed more goods and services than in all the previous generations put together. Unfortunately, the consumption and disposal mechanism is accelerating more and more. Since 1980, we have consumed onethird of the planet" (BOTSMAN and ROGERS, 2012, 56 ), and this is an easy path to the collapse of humanity as published by NASA and the World Bank.

The events that occurred in the last century were decisive and they deeply impacted society and the environment. The lack of a responsible attitude towards the use of natural resources, the ones that are nonrenewable and limited, has brought irreversible consequences. What can be perceived is a tacit battle between the great industries, which aim, for the most part, at wealth concentration and unlimited growth, and, on the other side, researchers, scholars, intellectuals and activists who seek to demonstrate how this system is unfeasible for life preservation on the planet, while proposing possible paths.

The first initiatives that took place in opposition to this scenario go back to the 1960s, just like the hippie movement. More recently, solutions that are aligned with the global permaculture and ecovillage movements argue that such challenges and problems can not be met by maintaining a consumerist lifestyle and a production that prioritizes profits at any cost. The current problems that we face cannot be solved in a capitalist consumption system, so this model should not be repaired, it must be replaced, as Trainer (2011) argues. These efforts seeking a new direction are being called the Transition Movement, which will be presented below.

\subsection{Transition Movement}

The concept of the Transition Movement was initially outlined in 2005 through research conducted by Hopinks ${ }^{1}$ (2008), the creator of the movement. At first the expression used to define the concept was "Cities in Transition," but along the way he realized that he was dealing with more than cities, expanding into villages, neighborhoods, islands, etc. And for this reason he understood that it would be more appropriate to identify it as "Transition Initiatives", leaving room to encompass any effort related to the society transition.

Thus, Transition Initiatives are defined as "emerging and evolving approaches to sustainability at the

\footnotetext{
${ }^{1}$ Rob Hopkins is an activist and researcher in the city of Totnes in England.
}

community level" (HOPKINS, 2008, p.87), and are based on four key assumptions: a) The need for a drastic reduction in energy consumption; b) That cities and communities prepare adequately for a possible oil and energy crisis; c) That it is necessary to act immediately in a collective way; And d) That by working collectively it is possible, creatively and proactively, to build a sustainable society.

Hopkins (2008) argues that reducing energy consumption does not mean decreasing life quality, and this action must be taken immediately. Each place will create its own conditions for this, the answers will emerge from the communities themselves, and undoubtedly, fostering a local economy would benefit the environment, promote a reduction of people's stress, and increase happiness.

The Transition concept was based on the permaculture principles, which, in essence, is a set of social, economic, cultural and technical premises that efficiently lead a community into becoming sustainable. Such premises were used to subsidize "the design and ethical foundations we use to support Transition work, to unite all elements of a post-peak agreement" (HOPKINS, 2008, p. 90)

According to Holmgren (2004), permaculture is a path that brings together design principles and philosophical foundations, but one that can remain distant from society. Hopkins (2008), on the other hand, wants to call on all holders of empirical, popular and/or scientific knowledge to learn together and thus develop alternatives for communicating with the greatest number of people in order to create unprecedented involvement. For Hopkins (2008) the permaculture concepts are implicit, but they support his concept of Transition.

It is worth noting that even being presented in different ways, both the principles of permaculture and transition have similarities and converge towards the same focal point: the desire to encourage, stimulate and guide society on how to change the current mental model of capitalist, consumerist and competitive consumption, for a frugal, collaborative way of life, and being aware of our actions and how we are part of a whole, both impacting and being impacted.

\section{Design for contemporary challenges}

Facing a societal collapse, as told above, together with initiatives in search of ways to exist, as expressed by the transition movement, we can see examples of new attitudes in design that take into account contemporary challenges such as: poverty, natural ecosystems jeopardy, unorganized human distribution, ineffective governance, economic instability, among other facts, as seen in the 17 Challenges of Sustainable Development ${ }^{3}$ established by the United Nations.

The Design field, which for a moment was understood as one related to functional or aesthetic issues, is now seen as a discipline that promotes

\footnotetext{
${ }^{2}$ Oil production reduction phase due to its exhaustion.

${ }^{3}$ http://www.un.org/sustainabledevelopment/
} 
innovation, and solves problems of different nature, bringing the individual to the center of the discussions, promoting empathy and results that are more appropriate to their reality, as Brown (2010) explains.

According to Cardoso (2012), when design emerged, its purpose was to organize the industrial world. The costs reduction and the consumer goods increase caused by the production technology and logistics increase characterized the period between the eighteenth and nineteenth centuries. "Never before in the history of mankind, so many people had had a chance to buy so many things. It was the infancy of consumer society" (CARDOSO, 2012, p.17).

The consequences to this action throughout years are nearly irreversible and the jeopardy of environment is evident, being imperative the commitment of designers and decision makers in search for ways of balancing economic interests together with society needs and conscious consumption, as proposed by authors such as Papanek (1995). Moreover, Botsman and Rogers (2012) point out that desire of consumerism continues to be influenced by design in a way that it is necessary to rethink what is created, in which way is produced as well as its relevance in terms of life cycle, taking into account premises such as the cradle to cradle perspective (BRAUNGART and MCDONOUGH, 2013).

As soon as designers are aware of the consequences of their work there will be a significant change in design, as postulated by Margolin (2014). For this reason it is urgent to understand the model of consumerism and capitalism that ignores environmental and social issues as a threat that no longer makes sense. It is hoped that designers back away from patterns that cultivate consumerism and take another way such as be engaged in decisions that take into account the environmental and social impacts. As point out by Clive Dilnot:

\begin{abstract}
The movement to a post-product society, i.e. society that considerate social management focussed on harmonic relations between people and environment, probably will bring us back the historical sense of relevance for design, being a tool for improving of quality of life more than merely a configuration of goods (apud MARGOLIN, 2014, p. 127).
\end{abstract}

It is common every day to find businesses, products and services that adopted sustainable practices, such as the "Original Unverpackt" 4, the first market to abandoned packaging in Berlin, or the "Eco cooler" ${ }^{5}$, an air conditioning without electricity, developed in Bangladesh by the company Grameen Intel Social Business. These examples illustrate how the knowledge in design as project discipline has solved different demands and social or economical realities with viable results and low impacts to nature.

In this direction we can see the use of methodologies focussed on solutions to major contemporary problems, such as: a) Design Thinking, from the well-known IDEO company, approaching critic and creative thoughts in

\footnotetext{
${ }^{4}$ http://original-unverpackt.de/

${ }^{5} \mathrm{http}$ ://www.grameen-intel.com/news/grameen-intelsclarification-eco-cooler/
}

order to develop solutions based on real needs; b) Dragon Dreaming, which are collaborative, creative and sustainable projects developed by the Australian John Croft, a specialist in businesses and sustainable projects; c) Business Model Generation - Canvas, used to develop innovative business models (Osterwalder and Pigneur, 2011), co-created by over 470 professionals; d) Service Design, aimed in creating significant experiences and improvement of interaction between companies and persons (Stickdorn and Schneider, 2011). Quoting some of a greater amount of methodologies.

These methodologies show how the design approach has been changing and prioritizing demands and social and environmental challenges in order to enhance the transition movement, according to two fundamental elements: creativity and leadership, considering design as a transversal knowledge, as follows.

\section{Creative leadership for the transition movement}

The Transition Movement and Design thinking are intertwined in many ways. At the moment when "design is focused more on facilitation than on object creation, on the transition from consumption to participation" (BOTSMAN and ROGERS, 2012, p. 157) we see a new rearrangement that prioritizes human experiences by placing the human needs at the heart of the discussion.

In order to promote the transition, this creative capacity and design skills are relevant resources even if they are not yet used in their full potential as stated by Manzini (2008), or even as researchers Ellen Winner and Lois Hetland (2007, apud EÇA , 2010), by stating that creative capacity is crucial in the sustainable economy.

This creative and inventive capacity characterizes design, being fundamental since "we need to have new choices, $[\ldots]$ new ideas that address the global challenges of health, poverty and education; new strategies that result in differences that matter and a sense of purpose that includes all the people involved" (BROWN, 2010, p.3). Regarding creativity, British government leaders meeting on May 22nd, 2008 to discuss the promotion of creativity and innovation through education and training (2008/C 141/10) ${ }^{6}$ concluded that:

Creativity is the main source of innovation, which in
turn is considered the main growth and wealth driver,
as a key factor for improvements in the social field
and an essential tool for tackling global challenges
such as climate change and sustainable development.

In this way, the creative leadership for the transition movement must go towards the engaged protagonism, in a local action, which does not necessarily mean to develop deeply elaborated strategies, but simple and effective actions that result in great impacts. Thus, the following examples illustrate how design can help build a post-consumer society.

\footnotetext{
${ }^{6}$ Available at $<$ http://eur-lex.europa.eu/legalcontent/EN/TXT/?uri=uriserv:OJ.C_.2008.141.01.0017.01.EN G\&toc $=$ OJ:C:2008:141:TOC $>$ Accessed on: 08/02/2017
} 
A contemporary need to recharge mobile phones can be solved in a way that goes beyond creativity, providing people with a break from everyday stress, in a place where people can sit and talk, so "Nature Recharges" is a kind of mobile garden, a solution provided by the partnership between A Shoot the Shit, a creative studio located in Porto Alegre (RS, Brazil) in collaboration with Zebú Mídias Sustentáveis ${ }^{7}$, a design office that assumes responsibility for the environment.

This collaborative initiative fulfills a series of principles of what is characterized as a transitional initiative, such as the humanization and occupation of urban spaces, the experience stimulation, community living, promoting well-being and reducing stress in large urban centers

Practical and limited in scope, the idea is already being shared on the internet, becoming an example so others can do the same. According to Hopkins (2008), this is the way contemporary thinking should be: it should have a global vision, but act locally, that is, know the examples around the world, but think about what can be done at the community level.

The proposition capacity of Design can be identified in this initiative, mainly in what concerns the idea of providing something that goes beyond the basic need of charging mobile phones, as it uses the skills of product development and visual identity to meet the undisclosed demands of an accelerated world, it is a countercurrent example: charge your mobile phone and, at the same time, take a break, enjoy a conversation, allow yourself to try another rhythm. In this way, design collaborates in the construction of "a world where the expectations of well-being are less associated to the existence of new artifacts" (Manzini, 2008, 57).

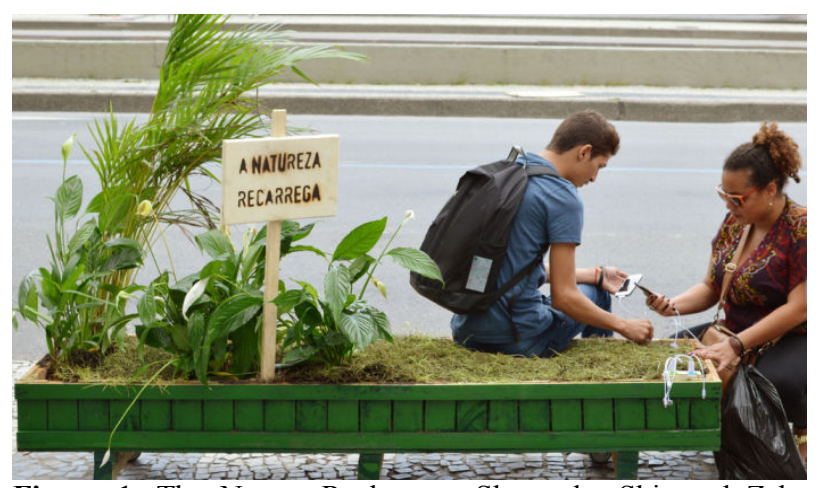

Figure 1. The Nature Recharges, Shoot the Shit and Zebu Media Available at: http://www.shoottheshit.cc/projetos/. Accessed on 14/02/2017.

In the case of the global movement called Design for Change, that has emerged in India and is called School Creatives in Brazil, teenagers and children are encouraged to change their surrounding environment through Design Thinking. All of this methodology content is available to download for free so that students can implement it. In 2016, in the awards promoted by the movement, 1014 projects were enrolled from both governmental and private schools all over Brazil. This tool provides free learning, autonomy and empowerment.

It is a deconstruction of paradigms about moral, civil and school education, at the moment it assists in the protagonism process, making people take a look at the problems that are in the surrounding environment. One of the projects is the one called "Paracoleta", implemented in Paraisópolis (SP, Brazil), with the purpose of stimulating the adequate waste collection by the population.

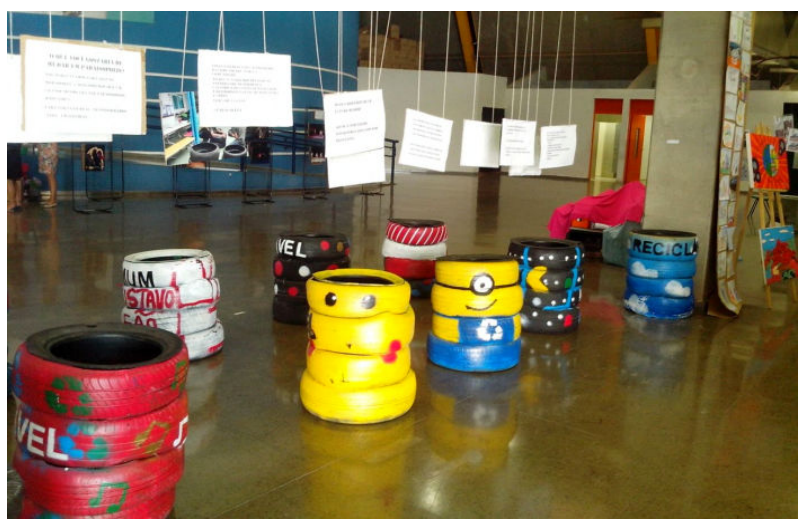

Picture 2. Paracoleta, School Creatives

Available at: http://criativosdaescola.com.br/paracoleta/. Accessed on 14/02/2017.

These practices within the school context meet what Hopkins (2008) proposes by stating that young people need to be prepared to deal with the demands of the world in a more pragmatic way when they leave school, be it cooking, gardening or making small repairs in their homes.

The biggest contribution of design thinking, according to Brown (2010) is to be a tool that can be used by people who have never thought about being designers but who can solve a variety of problems.

Talking about waste, other issues to be considered is the need to create and use environmentally friendly products, the reuse of materials, and thinking of the production chain as circular, as a way to reduce garbage production, waste and the environment pollution. It was with this purpose in mind that the Menos 1 Lixo movement, founded by activist Fernanda Cortez, developed a food silicone retractable cup and recyclable materials to reduce the amount of disposable cups used.

This initiative corroborates the transition movement by emphasizing individual responsibility for choices, as Hopkins (2008) explains, so that consumers are coresponsible for the results of what they consume.

\footnotetext{
${ }^{7}$ Their outstanding product was the development of organic paints containing a carton of more than 50 colors.
} 


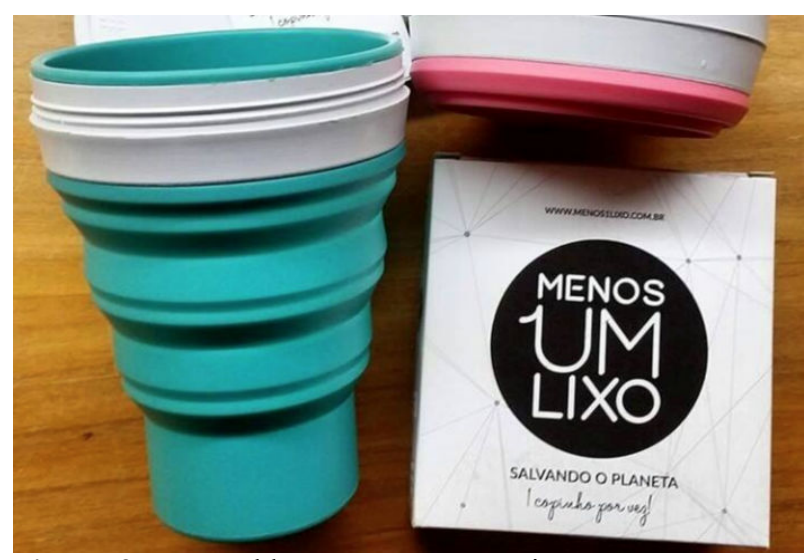

Picture 3. Retractable cup, Menos UM Lixo

Available at: https://www.facebook.com/menos1lixo/. Accessed on 14/02/2017.

This is the new design attitude, which stops developing products made to meet marketing and market strategies, and also the interests of a specific group and starts promoting conscious consumption, reduction and sharing. This is the case of "Tem Açúcar", an application that promotes the sharing of objects and tools among neighbors.

This application uses user experience (UX) principles and interface design to facilitate interaction between people in a simplified way. This demonstrates what scholars call the shift from design to design thinking, which involves designing experiences rather than products and objects, as Botsman and Rogers (2011) explain.

The action of sharing instead of buying changes not only our habits but it also impacts the economy, since it causes a consumption reduction. This new behavior can be motivated both by the economic crisis and the need to reduce expenses, as well as by an increasing awareness about the environmental impact of this consumption. According to Hopkins (2008), the economy is undergoing a transformation, and this causes people to create alternatives that favor the local economy strengthening, the creation of new exchange currencies and new business models.

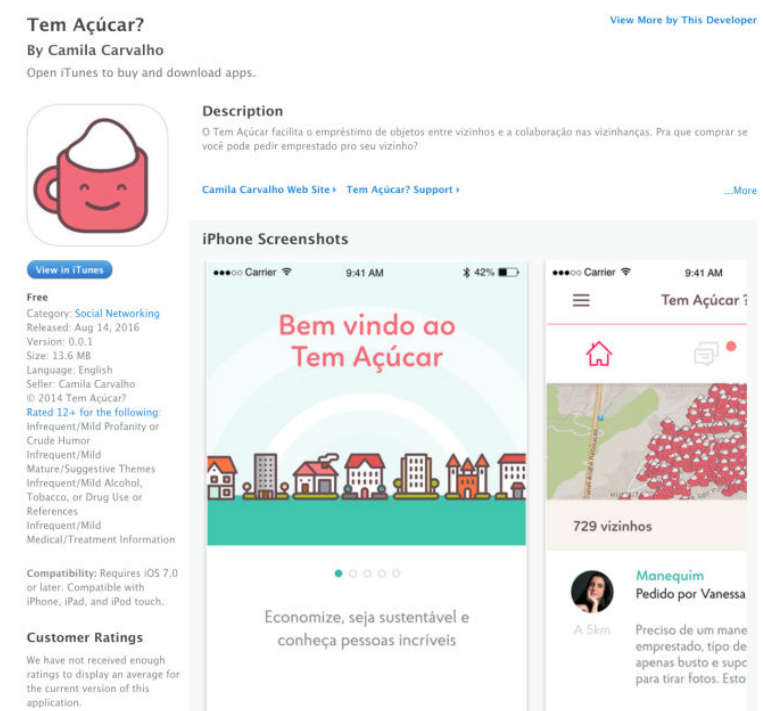

Picture 4. Tem Açúcar App
Available at: https://itunes.apple.com/br/app/temacucar/id1136121900?mt=8. Accessed on 14/02/2017.

In this way, we can see that design is able to collaborate with the transition movement through its principles, tools or methodology, be it in the development of new products and services, in the design of socio-environmental impact actions, in the creation of frugal solutions and in several other ways. This creative leadership, characterized by the ability to solve problems in an assertive and inspiring way, through the available resources, favors the construction of a new world and is of paramount importance to preserve the prospects of a prosperous and virtuous future.

\section{Final Considerations}

The complex problems of the post-capitalist world are evident. An attitude change is not optional. For this reason, this article aims to identify how design collaborates with the initiatives that follow in the construction of a new model of society that is economically viable, ecologically correct and socially just.

This study contributes to broadening the discussions about design as important knowledge for the transition movement. It reinforces the idea that the world in which design was conceived and the current one are entirely different and for this reason, this current world requires a new attitude, commitment and deep involvement in order to use knowledge for problem solving, and especially not to create new ones.

\section{References}

BOTSMAN, R.; ROGERS, R. O que é meu é seu: Como o consumo colaborativo vai mudar o seu o nosso mundo. Porto Alegre: Bookman, 2011.

BRAUNGART, M.; McDONOUGH, W.Cradle to cradle: Criar e reciclar ilimitadamente. São Paulo: Editora G. Gili, 2013.

BROWN, T. Design thinking: uma metodologia poderosa para decretar o fim das velhas ideias. Rio de Janeiro: Elsevier, 2010.

CARDOSO, R. Design para um mundo complexo. São Paulo: Cosac Naify, 2012.

CROFT, J. Dragon Dreaming. Disponível em: $<$ http://www.dragondreaming.org/>. Acesso em: 24 maio 2017.

EÇA, T. T. P. Educação através da arte para um futuro sustentável. Cad. Cedes, Campinas, vol. 30, n. 80, p. 1325, jan.-abr. 2010

HOLMGREN, D. Permacultura: princípios e caminhos além da sustentabilidade. Porto Alegre: Via sapiens, 2013.

HOPKINS, R. The transition Handbook: From oil dependency to local resilience. EUA: Chealsea Green Publishing, 2008. (PDF - Transition Handbook free edit version is released under GFDL and Creative Commons Attribution - Share Alike) 
MANZINI, E. Design para a inovação social $e$ sustentabilidade: comunidades criativas, organizações colaborativas e novas redes projetuais. Rio de Janeiro: E-papers, 2008.

MARGOLIN, V. Políticas do artificial: ensaios $e$ estudos sobre design. Rio de Janeiro: Record, 2014.

OSTERWALDER, A.; PIGNEUR, Y. Business Model Canvas - Inovação em Modelos de Negócios. Um Manual para Visionários, Inovadores e Revolucionários. Rio de Janeiro: Alta Books, 2011

PAPANEK, V. Arquitectura e Design. Lisboa: Edições 70, 1995.

SCHUMACHER, E. F. O Negócio é ser pequeno: um estudo de economia que leva em conta as pessoas. Rio de Janeiro: Zahar, 1983

STICKDORN, M; SCHNEIDER, J. Isto é Design Thinking de Serviços: Fundamentos, Ferramentas, Casos. 1. ed. Porto Alegre: Bookman, 2014.

TRAINER, T. The Global Significance of the Ecovillage Movement in MARE, E. C. and LINDEGGER, M. (org.) Designing Ecological Habitats Creating a Sense of Place. First edition. United Kingdom: Permanent Publications, 2011. 